\title{
Study on the Formation Mechanism of Commercial Housing Price
}

\author{
Lixin $\mathrm{Li}^{1,}$, , Lele Yang ${ }^{1, b}$ and Wenbo Fan ${ }^{1, \mathrm{c}}$ \\ ${ }^{1}$ School of Civil Engineering, Shenyang Jianzhu University,Shenyang 110168,China \\ alilixin1966@163.coml, b971424747@qq.com, ${ }^{c} 355156968 @ q q . c o m$
}

\begin{abstract}
Keywords: commercial housing price; formation mechanism; the theory of supply and demand Abstract. This article based on the basic theory of the formation mechanism of housing price, it introduced the fluctuations of commercial housing price in our country these years. Then by using the supply and demand theory, it analyzed the process of the commercial housing price formation mechanism and the main factors that can affect the price. Finally, it proposed some countermeasures and proposals about how to improve the formation mechanism of commercial housing price in our country.
\end{abstract}

\section{Introduction}

The housing problem is related to the social stability and development. It also matters if people can live peacefully. From the founding of new China to the present, China's housing has experienced the revolution from non-commodity to commodity, from physical housing allocation to the currency distribution.

After the reform of housing market in 1998, the real estate industry warming rapidly, the country began to develop the phenomenon of overheated real estate in 2003.In the year of 2003, the development and investment of real estate totaled 1.0106 trillion yuan, it increased $29.7 \%$ over the previous year according to the National Bureau of Statistics. The real estate investment accounted for the proportion of GDP also increased year by year, from $4.9 \%$ in 1999 to $8.7 \%$ in 2003.It was significantly higher than the general level of $5 \%{ }^{[1]}$. Facing the rapid growth of the housing price, the State Council issued " a notice on the practical stability of housing prices " (country 8) in March 26, 2005 , it put forward eight opinions on the stability of the price. In subsequent years, China's commercial housing price remained stable overall. The global financial crisis broke out in 2008, the volume and price come down in China's real estate market under the influence. There is a big turning point in our country in 10 tears. In this regard, the government has promulgated a series of plans to rescue the market, including deregulation of real estate credit, introduction of preferential interest rates and other measures. This makes the real estate in China recover rapidly in 2009, part of the cities appeared price rising rapidly. According to the National Bureau of Statistics, the real estate development and investment totaled 3.6232 trillion yuan, an increase of 16.1 percent over the previous year, while the real estate development and investment amounted to 4.8267 trillion yuan in 2010, an increase of 33.2 percent over the previous year ${ }^{[2]}$. In order to further strengthen and improve the regulation of real estate market, the State Council issued the "Notice on promoting the real estate market to develop stably and healthily "(country eleven) in January 2010. In April of the same year, the State Council promulgated the notice that curb the housing prices rise too fast in some cities resolutely "(new country ten). In the next three years, it increased by an average of $21.3 \%$ every year. To the year of 2013, the average selling price of commercial housing in our country rose from 1854 yuan in 1998 to 5850 yuan, an increase of nearly 2.2 times. In 2014, the overall macroeconomic environment is weak, the real estate market appears spontaneous callback. In 2015, the sale of commercial housing became warmer gradually. To February this year, the new housing construction area rises rapidly, the purchased land area narrowed significantly. The growth rate of development and investment of national real estate picked up for the first time after two years.

From the fluctuations of real estate price over the past 20 years, we can see that China's real estate industry has experienced several stages of rapid development, economic overheating, economic 
austerity to the economic adjustment. Although the country has set a series of macro-control policies to stabilize housing prices and prevent overheating growth in real estate, the effect of control is unsatisfactory. Many aspects of information from the market shows that the current housing market exists many problems: the imbalance between supply and demand, irrational structure, periodic excess supply and so on. These problems indicate that there are still many uncertainties and market risks in the development of housing industry in our country. As an important part of our national economy, the real estate industry, especially the development history of housing industry is short. Since entered the transition period, its price formation and the changes of main affecting factors still show a certain rule. Therefore, it is of great theoretical significance and practical value to choose the formation mechanism of housing price as the research topic.

By combing the literature at home and abroad, western developed market-economy countries with an emphasis on the role of government generally and pay more attention to the role of market mechanism and the influenced factors of housing price in housing price mechanism research. D.Denise, C.W William (1996) use a similar "cobweb theory" model to analyze the fluctuations in the housing market. At the same time, the residential market is divided into asset market and the use of market. From the concept of residential asset market and the use of market, this paper discusses the interaction between asset market and use of market ${ }^{[3]}$. Capozza(2004)analyzed the changes of American house price in 1979-1995.He found that the rise of house prices in the United States related to the American people's income growth, population growth and the level of domestic construction costs ${ }^{[4]}$. The analysis of the factors that affect the housing price is quite a lot in our country. Zhang Hong, Li Wendan(2001) argue that the rising cost of real estate construction is the main factor of housing prices. Wu Jianfeng (2002) believes that with the improvement of wage of urban residents in China, the improvement of residence requirement is the main factor of housing price.

So far, the history of the development of China's real estate market is not more than 20 years. Therefore, the domestic of the real estate market, especially the internal mechanism of the residential market research started late. Meanwhile these studies are limited to some qualitative description. Based on the above background, this paper analyzes the formation mechanism of the commercial housing price and the factors that affect housing price, and then launch the research work of this project. The development of the study is very necessary and important no matter for the government, or the developers and consumers.

\section{Commodity housing price related basic theory}

Definition of commercial housing

Housing is a type of real estate, it belongs to the residential real estate to serve the human living as the main purpose. In China's urban real estate market, it can be divided into commercial housing, affordable housing and the purchased public housing according to the different property rights. Commercial housing is sold by the market price. The price is regulated by the market itself with full property rights. It can be inherit, mortgage, lease and transfer. However, the affordable housing and the purchased public housing has been limited. The development of commercial housing is the market behavior for developers on the purpose of profit. Commercial housing will be the main way of housing supply in the future, but also the object of this study.

The concept of commercial housing price

Commercial housing price refers to the entirely market-oriented housing transaction price. It is the price composed of land leasing, urban community facilities construction fee, land acquisition and resettlement compensation, survey design and pre-construction costs, construction and installation costs, a cell below the rank of infrastructure fees, management fees, interest, taxes, cost of sales and developers profit ${ }^{[5]}$. Because the housing can not move, high value, complicated forming process and long production cycle, the formation of the commercial housing price is different from the general commodity. Commercial housing price "has the dual attributes of real-time price and process price". 
Process price reflects the formation of the residential value, the immediate price reflects the formation of residential price. Commodity housing price is the unity of real-time price and process price.

Characteristics of commercial housing price

(1) Regional. In different areas of the same city, the price is not the same even if the standard of commercial housing is exactly the same. Housing can not exists independently from the land .The housing price includes land price. Since the immobility of land, the location of the housing is different, the price of land is also different.

(2) One piece. Residential commodity in the location, size, quality and construction types can not be exactly the same. There is no homogeneous residential goods. And its formation process is very complex, which shows commercial housing price of a single piece.

(3) Policy. Characteristics of the land determine the allocation and adjustment of land resources should be directly involved in the government. The government's land use, planning and related policies have a significant impact on land price. When a piece of land is planned as a new urban center or new urban areas, the price of the land is likely to rise sharply.

(4) Volatility. Since commercial housing has a strong hedge against inflation, it's easy to have a hype. The feature of hype and affected by the policy makes the commodity price fluctuating.

Housing price structure

Housing price has two major components. One is the land price, another is the real estate price. The two parts interrelated, mutually influence and constraint each other, they form an organic whole together. From the composition point of view, housing price generally includes part of the land development fee, housing development costs, various ancillary taxes and the profit of developers.

\section{Theoretical basis of the formation mechanism of commercial housing price}

the concept of commercial housing price formation mechanism

"Mechanism", originated from Greek, refers to the machine structure and operation principle, later it was borrowing and playing by economics for illustrate the operation of the organism ${ }^{[6]}$. The price mechanism is the subsystem of the economic mechanism, it is the various elements which compose and affect the price according to certain principles of operation. The price is determined through mutual contact, mutual promotion and mutual restraint. Housing price mechanism as a system, it can be divided into formation mechanism of housing price, the operation mechanism of housing price and the information feedback mechanism of housing price from the process of its formation.

Price formation mechanism refers to the way of price formation and the specific conditions in a certain point, which is the core of the price mechanism. It includes the body of price formation, the specific manner of price formation and price determinants. Housing price formation mechanism as the basis of the price mechanism, it refers to the process, in market conditions, housing prices put housing production as a starting point under the joint action of the government, enterprises and consumers, around supply and demand as the core, make housing prices gradually established.

neoclassical equilibrium price theory

Neoclassical economic theory can be described as a marginal economic liberalism. The marginal revolution of 1870s marked the establishment of the new classical economic theory system. British school representative Marshall created the equilibrium price theory. Marshall put the supply and demand function theory, production cost and marginal utility as a whole and constructed his" equilibrium price". In his view, the equilibrium price of a commodity is the price when the supply price is equal to the price of the demand.

housing supply and demand equilibrium theory

housing demand theory

The demand for housing refers to the amount of residential consumers willing and able to buy in the market at a certain period of time and a certain price level. Specifically, residential demand is defined, in terms of the size of the population, family composition, age distribution and other conditions, the residential purchase volume which adapt to a certain amount of purchasing power and price levels. 
From the perspective of market economic analysis, the main research object is the housing demand. In addition to the residential demand, there is an important concept is the lowest living standards of state to estimate the demand for housing. It is also the required amount of residential starting from the basic needs of people.

housing supply theory

Housing supply refers to the sum of the number of available houses for sale in a given period of time, which is composed of newly built houses and the accumulated amount of housing in the previous year ${ }^{[7]}$. In general, the stock of housing occupies a large proportion in the whole residential real estate market due to the longer life of residential and slow loss of value. And with respect to this huge stock of housing, the number of new housing is negligible. From this point of view, the overall supply level of residential market is slowly adjusted.

\section{Overview of factors affecting the price of commercial housing}

economic factors

Real estate industry demand large amount of funds and long cycle, it needs to use financial leverage to compensate for the lack of its own funds. Such as changes in interest rates and tax rates will affect supply and demand of real estate, and they have an impact on real estate prices. In addition, the growth rate of the national economy, income level, price index and other economic factors will affect the formation of land prices.

administrative factors

Administrative factors influence the real estate price by regulating social and economic behavior. It mainly refers to the impact of real estate prices on the system, policies, regulations, administrative measures and other factors. The real estate market has a strong regional, when the land is planned for residential areas, commercial areas, industrial areas and other different regions, the impact on the price of land is great. When the government adjusts the function of a certain area, it will have an impact on the value in local real estate market. For example, the real estate is most likely to rise if you increase the infrastructure investment and construction of entertainment centers.

social factors

Human is the main subject of housing demand. Population is one of the basic factors that determine housing demand or market size. The quantity, quality and structure of people have a great impact on housing prices. At the same time, the social security system will have an impact on housing prices. If social security increases, the demand for commodity residential house will reduce and it will affect the price of commercial residential house. In addition, good neighborhood relations and harmonious community environment will have a significant impact on housing prices. From the perspective of the housing market development of our country, the role of the factors on the housing price is increasingly important.

real estate speculation factors

Real estate speculation refers to the behavior with commercial purposes, which utilize the changes of the real estate price in order to profit. Real estate speculation is established on the basis of the real estate price expectations for the future, it will cause real estate prices rise or fall.

\section{Conclusions and recommendations}

The formation mechanism of commercial housing price is the economic mechanism which based on the market price under the government's macroeconomic regulation and control. Commercial housing as the main body of China's real estate, the perfection of the mechanism is of great significance on the implementation of housing security system and the construction of a harmonious society in our country. Based on the above analysis, in order to further promote the rational development of commercial housing market, I think we should do from the following aspects to improve the commercial housing price formation mechanism. 
(1)Increase the total amount of housing supply

On the one hand, the government should improve the supply of new residential. On the other hand, they should pay more attention to the stock of housing supply, the supply of second-hand housing. This requires us to accelerate the secondary housing market and improve the system of the secondary housing market policy.

(2)Establish the market for effective demand

In the commercial housing market, the demand, especially the effective demand, is the ultimate power to promote the sustainable development of the market. Therefore, we should vigorously develop the economy, improve the income level of residents, especially disposable income, enhance purchasing power of residents and expand effective demand.

(3) Improve the housing market system and establish market operation mechanism.

The government should make rules, supervise the implementation of the rules and impose penalties on those who violate the rules. Create a fair competitive environment in the further strengthening of the housing system reform to break the monopoly and introduce competition. In addition, the government should assume the responsibility to protect the low-income residential housing, establish and improve housing security system.

(4)Lead to establish scientific housing construction and consumption patterns

To establish a reasonable mode of housing construction, we should vigorously develop energy-saving, land-saving and environmental friendly buildings, advocate "rent, sell both" scientific patterns of consumption according to spending ability and establish a reasonable model of housing construction of ordinary residents.

\section{Acknowledgements}

This work was financially supported by the Shanghai Natural Science Foundation (0666666), Innovation Program of Shanghai Municipal Education Commission (060000) and Shanghai Leading Academic Discipline Project of Shanghai Municipal Education Commission (0555555).

\section{References}

[1] Information on http://www.villas.com.cn

[2] National Bureau of Statistics, Statistical bulletin of the national economic and social development of China(2011)

[3] Denise Dipasquale, William C.Wheaton, in: Urban Ecomomics and Real Estate[M](2000)

[4] Capozza, Dennis R., P. H. Hendershott and Charlotte Mack. An Anatomy of Price Dynamics in Illiquid Markets: Real Estate Eonomics(2004)

[5] Qian changrun and Lu Jinfeng Real Estate Economics[M]. Beijing: China Planning Press(1999)

[6] Dong Pan, Real Estate Finance [M]. Liaoning: Dongbei University of Finance and Economics Press(2000)

[7] Tan Gang, Real Estate Cycle [M]. Beijing: Economic Management Publishing House (2001) 